\title{
TROMBOSITOSIS : FAKTOR RISIKO PENINGKATAN PENYEMPITAN PEMBULUH DARAH PADA PETANI, BURUH, DAN PENAMBAK IKAN YANG MERUPAKAN PEROKOK AKTIF DI KELURAHAN TANJUNG PINANG KOTA PALANGKA RAYA
}

\author{
Rinny Ardina ${ }^{1}$ \\ 1'Dosen Program Studi D-III Analis Kesehatan, Fakultas IImu Kesehatan, \\ Universitas Muhammadiyah Palangkaraya, Palangka raya, Kalimantan Tengah \\ e-mail : rinyardina@gmail.com
}

\begin{abstract}
ABSTRAK
Perokok aktif merupakan orang yang merokok secara aktif atau terus-menerus. Populasi perokok di Provinsi Kalimantan Tengah adalah 26,5\%. Berdasarkan jenis pekerjaan, petani, nelayan/penambak ikan, dan buruh adalah proporsi perokok terbesar (44,5\%) dibandingkan kelompok pekerjaan lainnya. Mayoritas perokok aktif di Kelurahan Tanjung Pinang Kota Palangka Raya terutama yang tinggal di Jl. Bengaris bekerja sebagai petani, buruh, dan penambak ikan. Perokok aktif mempunyai risiko tinggi menderita penyakit jantung. Kandungan rokok dapat mengakibatkan disfungsi jaringan endotelial pada pembuluh darah jantung disertai pembentukan trombus karena meningkatnya jumlah trombosit dan juga agregasi trombosit. Tujuan dalam penelitian ini adalah untuk memberikan gambaran jumlah trombosit pada perokok aktif yang tinggal di Jl. Bengaris Kelurahan Tanjung Pinang Kota Palangka Raya. Metode yang digunakan dalam penelitian ini adalah metode observasional study dengan pendekatan deskriptif. Jumlah sampel yang didapatkan adalah sebanyak 48 orang dengan menggunakan teknik purposive sampling dengan kriteria: perokok aktif, laki-laki, bekerja sebagai petani, buruh, atau penambak ikan, tidak memiliki riwayat penyakit, dan bersedia menjadi responden. Pemeriksaan jumlah trombosit dilakukan dengan metode otomatis menggunakan Hematology Analyzer. Hasil penelitian menunjukkan rata-rata responden berusia $20-30$ tahun $(35,4 \%)$ dan $31-40$ tahun $(31,2 \%)$, bekerja sebagai petani $(43,7 \%)$ dan buruh $(41,7 \%)$, lama merokok 1-10 tahun $(37,5 \%)$ dengan jumlah konsumsi merokok yaitu 11-20 batang/hari $(41,7 \%)$, dan waktu istirahat yaitu mayoritas $>6$ jam/hari $(64,6 \%)$. didapatkan perokok aktif dengan jumlah trombosit tinggi sebanyak 1 orang (2,1\%) dan jumlah trombosit normal sebanyak 47 orang $(97,9 \%)$.
\end{abstract}

Kata Kunci: Perokok Aktif, Trombosit, Petani, Buruh, Penambak Ikan, Hematology Analyzer

\begin{abstract}
Active smokers are people who are smoking continuously. The population of active smokers in Central Kalimantan was $26,5 \%$ in 2013 . The farmer, fish farmer and laborer had large proportion $(44.5 \%)$ as an active smokers than another job that reported according to types of jobs. Cigarettes contain many of toxic and addictive chemicals. Majority of active smokers that was living in Kelurahan Tanjung Pinang Kota Palangka Raya, especially who live in Jl. Bengaris works as farmer, fish farmer, or laborer. Active smokers have high risk of suffering from heart disease. Cigarette compound that harmful can cause endothelial tissue dysfunction in heart
\end{abstract}


Faktor-Faktor Yang Mempengaruhi Keikutsertaan Bidan Praktik Mandiri Pada Program Jaminan Kesehatan Nasional Di Kota Palangka Raya

blood vessels and following by thrombus formation that due to increased platelet counts and platelet aggregation. This study aimed to describe of platelet count in active smokers in Jl. Bengaris Kelurahan Tanjung Pinang, Palangka Raya. Descriptive observational method was used in this study. Sample obtained by 48 people with purposive sampling technique with criteria such as active smokers, men, working as farmers, fish farmers,or laborers, no history of disease, and willing to be respondent. Examination of platelet count was done by hematology analyzer. The average of respondents aged $20-30$ years $(35.4 \%)$ and $31-40$ years $(31.2 \%)$, worked as farmers (43.7\%) and laborers (41.7\%), duration of smoking were $1-10$ year $(37.5 \%)$, consumption of smoking was 11-20 cigarettes / day (41.7\%), and rest periods were $>6$ hours / day $(64.6 \%)$. There was one person of active smoker with a high platelet count $(2.1 \%)$ and normal platelet count of 47 people (97.9\%).

Keywords: Active Smokers, Platelet, Farmer, Fish Farmer, Laborer, Hematology Analyzer

\section{PENDAHULUAN}

Perokok adalah seseorang yang suka merokok, disebut perokok aktif bila orang tersebut yang merokok secara aktif. Pada tahun 2003 negara-negara anggota WHO (World Health Organization) mulai mengadopsi konvensi untuk memerangi efek mematikan yang ditimbulkan dari konsumsi tembakau. Menurut WHO lebih dari $70 \%$ anak Indonesia terpapar asap rokok dan menanggung resiko terkena berbagai penyakit akibat asap rokok.

\section{Global Adults Tobacco Survey}

(GATS) tahun 2011 mengatakan sekitar 2/3 perokok di dunia tinggal di 10 negara dan Indonesia menempati urutan ke-4 dengan jumlah perokok (4\%) setelah Cina (38\%), Rusia (7\%) dan Amerika Serikat (5\%). Berdasarkan Riset Kesehatan Dasar (Riskesdas) Tahun 2013 rerata proporsi perokok saat ini di Indonesia adalah $(29,3 \%)$. Proporsi perokok di Provinsi Kalimantan Tengah sebesar 26,5\%.
Berdasarkan kelompok umur proporsi terbanyak perokok aktif setiap hari pada umur 30-34 tahun sebesar 33,4\%, umur 3539 tahun sebesar 32,2\%, sedangkan berdasarkan jenis kelamin perokok laki-laki lebih banyak $(47,5 \%)$ dibandingkan perokok perempuan $(1,1 \%) .{ }^{1,2}$

Asap rokok terdiri dari asap utama (main stream) yang mengandung 25 persen kadar bahan berbahaya dan asap sampingan (side stream) yang mengandung 75 persen kadar bahan berbahaya. ${ }^{3}$ Asap rokok mengandung lebih dari 4000 bahan kimia berbahaya, diantaranya nikotin, tar, timbal, karbonmonoksida (CO), polynuclear aromatic hydrocarbons, tobbaco-specific $N$ nitrosamines and aromatic amines, dan berbagai radikal bebas lainnya yang bersifat karsinogenik. ${ }^{4}$ Setiap hembusan asap rokok dari perokok aktif mengandung $10^{15}$ radikal bebas oksidatif yang merupakan sumber utama penyebab stres oksidatif yang berpotensi sebagai mediator disfungsi 
endotelial, peningkatan trombogenesitas darah, dan respon inflamasi. ${ }^{5,6}$

Perkembangan penyakit jantung koroner akibat asap rokok dimulai dari disfungsi jaringan endotelial pada pembuluh darah jantung yang menimbulkan pembentukan trombus di dinding pembuluh darah. ${ }^{6}$ Disfungsi endotelial disebabkan oleh berkurangnya produksi atau persediaan NO, dimana konsentrasi nitrit dan nitrat di dalam serum yang merupakan produk akhir metabolik dari NO mengalami penurunan akibat asap rokok. Selanjutnya, di dalam tubuh akan terjadi agregasi trombosit yang berlebihan pada dinding endotelial. $^{7}$

Mekanisme inflamasi juga merupakan salah satu faktor utama perkembangan penyakit jantung koroner. Inflamasi ditandai dengan aktivasi trombosit dan berakibat pada pengikatan sejumlah trombosit di dinding endotelial pembuluh darah. Trombosit yang meningkat di dalam darah berfungsi untuk mensekresikan kemokin dan sitokin yang mampu memediasi inflamasi pembuluh darah akibat senyawa radikal bebas dari asap rokok. ${ }^{5}$ Peningkatan agregasi trombosit di dinding pembuluh darah yang terus-menerus dapat menyebabkan inflamasi dan kejadian aterosklerosis.

Berdasarkan jenis pekerjaan, petani, nelayan/penambak ikan, dan buruh adalah proporsi perokok setiap hari yang terbesar
$(44,5 \%)$ dibandingkan kelompok pekerjaan lainnya. $^{2}$ Mayoritas perokok aktif di Kelurahan Tanjung Pinang Kota Palangka Raya terutama yang tinggal di Jl. Bengaris RT. 01/RW. 03 mayoritas penduduknya bekerja sebagai petani, buruh, dan penambak ikan. Oleh sebab itu, peneliti mengambil lokasi tesebut sebagai lokasi untuk penelitian. Tujuan dari penelitian ini ialah untuk memberikan gambaran jumlah trombosit pada perokok aktif yang tinggal di Jl. Bengaris Kelurahan Tanjung Pinang Kota Palangka Raya.

\section{METODOLOGI}

Penelitian ini menggunakan metode observasional deskriptif, yaitu suatu metode yang digunakan untuk menggambarkan jumlah trombosit sebagai salah satu faktor risiko penyempitan pembuluh darah pada petani, buruh atau penambak ikan yang merupakan perokok aktif yang tinggal di J. Bengaris Kelurahan Tanjung Pinang Kota Palangka Raya. Adapun langkah-langkah penelitian yang dilakukan antara lain: pengumpulan data, klasifikasi, dan pengolahan/analisis data.

Sampel diambil dengan menggunakan teknik purposive sampling dengan kriteria : perokok aktif, berjenis kelamin laki-laki, bekerja sebagai petani, buruh, atau penambak ikan, tidak memiliki riwayat penyakit, dan bersedia menjadi 
Faktor-Faktor Yang Mempengaruhi Keikutsertaan Bidan Praktik Mandiri Pada Program Jaminan Kesehatan Nasional Di Kota Palangka Raya

responden. Didapatkan sampel sebanyak 48 orang.

Pengambilan sampel dilakukan dengan melakukan observasi terlebih dahulu diikuti pembagian lembar inform consent kepada responden. Setelah memperoleh persetujuan dari responden, dilakukan wawancara dengan bantuan angket yang berisi beberapa pertanyaan. Selanjutnya dilakukan proses pengambilan darah vena menurut prosedur baku dari Departemen Kesehatan RI (2008) dengan alat dan bahan antara lain spuit $3 \mathrm{cc}$, tabung vakum ungu ( $\left.\mathrm{K}_{3} \mathrm{EDTA}\right)$, tourniquet, kapas alkohol 70\%, dan plester. Pemeriksaan hitung jumlah trombosit menggunakan metode otomatis dengan alat dan bahan antara lain Hematology Analyzer, sampel darah EDTA, reagen stromalyse, dan cell clean. ${ }^{8}$

Data yang diperoleh dari hasil wawancara dan pemeriksaan jumlah trombosit selanjutnya dimuat dalam bentuk tabel yang terdiri dari kode sampel, parameter pemeriksaan, hasil pemeriksaan dan keterangan. Data dalam tabel kemudian dianalisis dan dideskripsikan dalam bentuk persentase (\%) menurut Sudijono (2010). ${ }^{9}$

\section{HASIL DAN PEMBAHASAN}

Individu yang dijadikan subjek dalam penelitian ini berjumlah 48 orang yang merupakan perokok aktif yang tinggal di perumahan Jl. Bengaris, Kelurahan Tanjung Pinang, Kota Palangka Raya. Pada tabel 1 menunjukkan bahwa rata-rata responden berusia $20-30$ tahun $(35,4 \%)$ dan $31-40$ tahun $(31,2 \%)$, bekerja sebagai petani $(43,7 \%)$ dan buruh $(41,7 \%)$, lama merokok 1-10 tahun (37,5\%) dengan jumlah konsumsi merokok yaitu 11-20 batang/hari $(41,7 \%)$, dan waktu istirahat yaitu mayoritas $>6$ jam/hari $(64,6 \%)$.

TABEL 1. Karakteristik Responden

\begin{tabular}{|c|c|c|}
\hline \multirow{2}{*}{$\begin{array}{c}\text { Karakteristik } \\
\text { Responden }\end{array}$} & \multicolumn{2}{|c|}{ Frekuensi } \\
\hline & $\begin{array}{c}\underset{N}{\text { Jumlah }} \\
\mathrm{N}=48\end{array}$ & $\begin{array}{c}\text { Persentase } \\
(\%)\end{array}$ \\
\hline \multicolumn{3}{|c|}{ Usia (tahun) } \\
\hline $20-30$ & 17 & 35,4 \\
\hline $31-40$ & 15 & 31,2 \\
\hline $41-50$ & 9 & 18,8 \\
\hline $51-60$ & 7 & 14,6 \\
\hline \multicolumn{3}{|l|}{ Pekerjaan } \\
\hline Petani & 21 & 43,7 \\
\hline Buruh & 20 & 41,7 \\
\hline Penambak ikan & 7 & 14,6 \\
\hline \multicolumn{3}{|l|}{$\begin{array}{l}\text { Lama Merokok } \\
\text { (tahun) }\end{array}$} \\
\hline $1-10$ & 18 & 37,5 \\
\hline $11-20$ & 16 & 33,3 \\
\hline$>20$ & 14 & 29,2 \\
\hline \multicolumn{3}{|c|}{ Jumlah Konsumsi } \\
\hline $1-10$ & 13 & 27,1 \\
\hline $11-20$ & 20 & 41,7 \\
\hline$>20$ & 15 & 31,2 \\
\hline \multicolumn{3}{|l|}{$\begin{array}{l}\text { Waktu Istirahat } \\
\text { (jam/hari) }\end{array}$} \\
\hline $1-6$ & 17 & 35,4 \\
\hline$>6$ & 31 & 64,6 \\
\hline
\end{tabular}

Hasil penelitian ini menunjukkan bahwa usia merokok yang paling banyak adalah pada rentang 20-30 tahun dan 31-40 tahun. Kelompok usia perokok terbanyak ini juga dilaporkan oleh Hidayat and Thabrany (2008) dimana diperoleh rata-rata usia 
merokok adalah 20,8 tahun dan berdasarkan data Riskesdas tahun 2013 bahwa rentang usia perokok terbanyak ditemukan pada usia 30-34 tahun. ${ }^{10}$

Berdasarkan jenis pekerjaan menurut data Riskesdas tahun 2013, petani/penambak ikan/buruh adalah proporsi perokok aktif setiap hari yang terbesar (44,5\%) dibandingkan kelompok pekerjaan lainnya. Dalam penelitian ini didapatkan mayoritas perokok terbanyak adalah bekerja sebagai petani dan buruh.

Adapun berdasarkan lama merokok, responden dalam penelitian ini paling banyak dengan lama merokok antara 1-20 tahun, dimana ini juga dilaporkan dalam penelitian Sundari, et al (2015) yang menemukan rata-rata lama merokok perokok sekitar 3-25 tahun. Jumlah rokok yang dikonsumsi oleh responden mayoritas adalah 11-20 batang/hari, hasil ini juga didukung oleh data Riskesdas tahun 2013 yang melaporkan rerata jumlah batang rokok yang dihisap oleh perokok aktif di Indonesia adalah sekitar 12,3 batang/hari. Serupa dengan penelitian Sundari, et al (2015) dimana ditemukan mayoritas perokok mengonsumsi rokok sebanyak 1120 batang/hari (70,9\%) dan penelitian Sarfaraz, et al (2016) pada populasi di Karachi yang juga melaporkan bahwa perokok aktif paling banyak mengonsumsi rokok >10 batang/hari. ${ }^{11,2,12}$
Mayoritas responden atau perokok memiliki waktu istirahat $>6$ jam/hari $(64,6 \%)$. Waktu istirahat dalam hal ini adalah waktu yang dibutuhkan oleh responden untuk tidur dari malam hari hingga bangun pagi keesokan harinya. Tidur merupakan proses yang sangat dibutuhkan oleh tubuh untuk pembentukan sel-sel yang rusak, memberi waktu organ tubuh untuk beristirahat maupun untuk menjaga keseimbangan metabolisme dan biokimiawi tubuh. Kualitas tidur yang kurang akan berdampak bagi tubuh karena proses biologis yang terjadi saat tidur akan terganggu terutama dalam hal ini adalah mekanisme perbaikan kerusakan akibat radikal bebas dari asap rokok. ${ }^{13}$

TABEL 2. Jumlah Trombosit Perokok Aktif

\begin{tabular}{lcc}
\hline \multirow{2}{*}{ Jumlah Trombosit } & \multicolumn{2}{c}{ Frekuensi } \\
\cline { 2 - 3 } & $\begin{array}{c}\text { Jumlah } \\
(\mathbf{n})\end{array}$ & $\begin{array}{c}\text { Persentase } \\
(\%)\end{array}$ \\
\hline Normal & 47 & 97,9 \\
\hline Tinggi & 1 & 2,1 \\
\hline
\end{tabular}

Tabel 2 menunjukkan bahwa perokok aktif yang memiliki jumlah trombosit tinggi (trombositosis) adalah 1 orang $(2,1 \%)$ dan ini ditemukan pada perokok aktif berusia 21 tahun, bekerja sebagai buruh, lama merokok antara 1-10 tahun dengan durasi merokok setiap hari. Jumlah rokok yang dikonsumsi responden ini adalah > 20 batang/hari dengan waktu istirahat $>6$ jam/hari. 
Faktor-Faktor Yang Mempengaruhi Keikutsertaan Bidan Praktik Mandiri Pada Program Jaminan Kesehatan Nasional Di Kota Palangka Raya

Diketahui responden ini merokok > 5 tahun dan ini juga diungkapkan oleh Misra and Vankatesh (2018) bahwa jumlah trombosit meningkat pada perokok dengan lama merokok minimal 5 tahun. Selain itu, konsumsi rokok > 20 batang/hari dapat menyebabkan makin banyaknya komponen berbahaya dari asap rokok yang terhisap dan keadaan ini yang mengawali mekanisme respon inflamasi diantaranya peningkatan jumlah trombosit. ${ }^{14}$

Akan tetapi temuan trombositosis dalam penelitian ini sangatlah minim. Lebih banyak ditemukan perokok yang mengonsumsi rokok 11-20 batang/hari, namun tidak menunjukkan adanya peningkatan jumlah trombosit. Hasil ini bertentangan dengan penelitian Kabier (2015) yang menemukan bahwa tidak ada perbedaan yang signifikan antara perokok yang mengonsumsi < 10 batang/hari dengan > 10 batang/hari dimana pada kedua kelompok ini sama-sama didapatkan jumlah trombosit tinggi. ${ }^{15}$

Dalam penelitian Kim, et al (2014) dibuktikan bahwa trombositosis secara signifikan berhubungan dengan merokok. Secara umum diketahui bahwa asap rokok mampu menimbulkan respon inflamasi yang pada akhirnya menyebabkan peningkatan jumlah trombosit. ${ }^{16}$ Maraz, et al (2013) juga menyatakan hal serupa dimana trombositosis secara signifikan lebih banyak ditemukan pada perokok aktif $(26,1 \%)$. Cukup banyaknya perokok dengan trombositosis yang ditemukan dalam penelitian Maraz, et al dibandingkan dalam penelitian ini juga dikarenakan kondisi responden Maraz, et al yang telah mengalami penyakit kronik berupa kanker paru yang diakibatkan oleh merokok. ${ }^{17}$

TABEL 3. Hasil Temuan Agregat Trombosit Pada Alat Otomatis

\begin{tabular}{lcc}
\hline & \multicolumn{2}{c}{ Frekuensi } \\
Temuan Hasil & \multicolumn{2}{c}{$\mathbf{n = 4 8}$} \\
\cline { 2 - 3 } Trombosit & $\begin{array}{c}\text { Jumlah } \\
\text { (n) }\end{array}$ & $\begin{array}{c}\text { Persentase } \\
\text { (\%) }\end{array}$ \\
\hline Agregat & 10 & 20,8 \\
\hline Normal & 38 & 79,2 \\
\hline
\end{tabular}

Pada tabel 3 dapat dijelaskan alasan mengapa perokok aktif dengan jumlah trombosit tinggi ditemukan sangat sedikit $(2,1 \%)$ dalam penelitian ini. Alat otomatis mendeteksi adanya agregat trombosit yang muncul pada sampel saat dilakukan pengukuran pada 10 responden $(20,8 \%)$. Keberadaan agregat yang terdeteksi ini dapat menyebabkan hasil jumlah trombosit menjadi rendah palsu (atau jumlah trombosit menjadi terbaca normal) walaupun mungkin jumlah trombosit yang sebenarnya jauh lebih tinggi daripada yang terbaca oleh alat. ${ }^{18}$

Agregat trombosit yang muncul pada darah perokok aktif diawali dengan adanya peningkatan jumlah trombosit yang menyebabkan agregasi trombosit secara berlebihan. Peningkatan jumlah trombosit di 
sirkulasi disebabkan sumsum tulang menstimulasi produksi trombosit yang banyak akibat dari paparan kimia asap rokok. Trombosit memiliki kecenderungan untuk mudah melekat pada partikel asing lalu trombosit melepaskan nukleotida dan beberapa komponen sel lainnya sebagai bentuk respon terhadap paparan partikel asing tersebut. Hilangnya nukleotida ini yang menyebabkan perubahan struktural pada trombosit. Nikotin merupakan partikel asing yang secara langsung menyebabkan perubahan pada struktur trombosit yang memediasi inflamasi dan agregasi trombosit. ${ }^{19}$

Beberapa mekanisme yang menyebabkan peningkatan jumlah trombosit yaitu 1) sifat trombosit yang memiliki kecenderungan untuk mudah melekat pada partikel asing seperti nikotin. Perlekatan ini menstimulasi trombosit untuk melepaskan nukleotida dan beberapa komponen sel lainnya sehingga terjadi perubahan struktural trombosit, 2) radikal bebas yang terhirup dari asap rokok dapat memecah nitric oxide sehingga meningkatkan sintesis tromboksan sekaligus penurunan produksi prostasiklin (aktivitas antirombik), sehingga menyebabkan gangguan pada sistem koagulasi, dan 3) penurunan sensitivitas prostasiklin memicu peningkatan trombosis. ${ }^{14,20}$

\begin{tabular}{ccc}
\multicolumn{2}{c}{ Pengaktifan trombosit yang } \\
berlebihan dapat meningkatkan risiko
\end{tabular}

pembentukan trombus (sumbatan) bersamaan dengan rusaknya lapisan arteri, yang dapat berkembang menjadi aterosklerosis. Trombosit mengalami perubahan bentuk selama aktivasi dimana bentuknya berubah dari discoid menjadi sferis (bola) dan terbentuk pula pseudopodia yang menyebabkan ukuran rombosit tampak lebih besar. Trombosit yang membesar ini memiliki sifat lebih perekat dan cenderung membentuk agregat dibandingkan saat ukurannya kecil/normal. Dalam penelitian Yarlioglues, et al., (2012) paparan dari asap rokok mempengaruhi perubahan bentuk dari trombosit sesuai dengan durasi dan intensitas paparan asap. $^{21}$

\section{KESIMPULAN}

1. Rata-rata responden berusia 20-30 tahun $(35,4 \%)$ dan $31-40$ tahun $(31,2 \%)$, bekerja sebagai petani $(43,7 \%)$ dan buruh $(41,7 \%)$, lama merokok 1-10 tahun (37,5\%) dengan jumlah konsumsi merokok yaitu 11-20 batang/hari $(41,7 \%)$, dan waktu istirahat yaitu mayoritas $>6$ jam/hari (64,6\%).

2. Perokok aktif dengan jumlah trombosit tinggi sebanyak 1 orang $(2,1 \%)$ dan jumlah trombosit normal sebanyak 47 orang $(97,9 \%)$.

3. Ditemukan adanya agregat trombosit pada 10 responden $(20,8 \%)$. 
Faktor-Faktor Yang Mempengaruhi Keikutsertaan Bidan Praktik Mandiri Pada Program

Jaminan Kesehatan Nasional Di Kota Palangka Raya

\section{DAFTAR PUSTAKA}

1. WHO. 2011. Global Adult Tobacco Survey : Indonesia Report 2011. Indonesia.

2. Badan Penelitian dan Pengembangan Kesehatan. 2013. Riset Kesehatan Dasar 2013. Kementerian Kesehatan RI.

3. Nurjanah, Lily, K., dan Abdun, M. 2014. Jurnal Kesehatan Masyarakat. 10 (1) : 43-52.

4. Lymperaki, E., Makedou, K., lliadis, S., and Vagdatli, E., 2015. Effects of Acute Cigarette Smoking on Total Blood Count and Markers of Oxidative Stress in Active and Passive Smokers. Hippokratia. 19 (4) : 293-297.

5. Vardavas, C. I., and Demosthenes, B. P. 2009. The Causal Relationship Between Passive Smoking and Inflammation on the Development of Cardiovascular Disease : A Review of the Evidence. Inflammation and Allergy - Drug Targets. 8 (5) : 328-333.

6. Lavi, S., Abhiram, P., Eric, H. Y., et al. 2007. Smoking is Associated with Epicardial Coronary Endothelial Dysfunction and Elevated White Blood Cell Count in Patients with Chest Pain and Early Coronary Artery Disease. Circulation. 115 : 2621-2627.

7. Yanbaeva, D. G., Mieke, A. D., Eva, C. et al. 2007. Systemic Effects of Smoking. CHEST. 131 (5) : 1557-1566.

8. Departemen Kesehatan Republik Indonesia. 2008. Pedoman Praktik Laboratorium yang Benar. Jakarta : Depkes RI.

9. Sudijono, A. 2010. Pengantar Statistik Pendidikan. Rajawali Press : Jakarta.

10. Hidayat, B., dan Thabrany H. 2008. Model Spesifikasi Dinamis Permintaan Rokok: Rasionalkah Perokok Indonesia?. Jurnal Kesehatan Masyarakat Nasional. 3 (3): 99-108.

11. Sundari, R., Dinyar, S.W., dan Aditia, N. 2015. Lama Merokok dan Jumlah Konsumsi Rokok terhadap Trombosit pada Laki-laki Perokok Aktif. Jurnal Kesehatan Masyarakat Nasional. 9 (3) : 257-263.

12. Sarfaraz, S., Aniqa, A., Bisma, S., Husna, N., Ramsha, K., Uzma, H., and Wajeeha, F. 2016. Passive Smoking: Silent Threat to the Female Population of Karachi. RADS Journal of Pharmacy and Pharmaceutical Sciences. 4 (1) : 188193.

13. Sarjono, L., Pandelaki, dan Onkowijaya. 2016. Perbedaan Kadar Hemoglobin Pada Mahasiswa Fakultas Kedokteran Universitas Samratulangi Berdasarkan Kualitas Tidur. Jurnal e-Clinik (e-Cl). 4 (2) : 1-4.

14. Misra, J., and Vankatesh, K. 2018. Comparison of Platelet Count in Smokers Versus Non-Smokers. Journal of Evidence Based Medicine and Healthcare. 5 (19) : 1522-1528.

15. Kabier, W.A.M.A. 2015. Determination of Some Hematological Parameters among Healthy Smokers in Khartoum State. Sudan University of Science and Technology.

16. Kim, M., Hyun, C., Hee Chul, Y., Yu Jung, K., Choon-Taek, L., Jae-Ho, L., Sanghoon, J., Kwhanmien, K., JinHaeng, C., and Jong Seok, L. World 2014. Preoperative Thrombocytosis is a Significant Unfavorable Prognostic Factor for Patients with Resectable Non-Small Cell Lung Cancer. Journal of Surgical Oncology. 12 (37) : 1-6.

17. Maraz, A., Jozsef, F., Zoltan, V., Zsuzsanna, K., Laszlo, T., and Katalin, H. 2013. Thrombocytosis Has a Negative Prognostic Value in Lung Cancer. ANTICANCER RESEARCH. 33 : 17251730.

18. Bourges-Abella, N., Anne, G., Didier, C., Jean-Pierre, B., and Catherine, T. 2011. Canine Reference Intervals for The Sysmex XT-2000iV Hematology Analyzer. Veterinary Clinical Pathology. 40 (3) : 303-315.

19. Aftab, K. U., and Al Shammari, M. 2015. Impact of Nicotine On Hematological Parameters and Its Comparative Studies 
Rinny Ardina

on Active and Passive Smokers. European Journal of Pharmaceutical and Medical Research. 2(6) : 79-82.

20. Leone, A. 2011. Passive Smoking and Infectious Disease: A Serious Hazard for Cardiovascular System. International Journal of Clinical Medicine. 2 : 550-555.

21. Yarlioglues, M., Idris, A., Orhan, D., and et al. 2012. The Acute Effects of Passive Smoking on Mean Platelet Volume in Healthy Volunteers. Angiology. 63 (5) : 353-359. 